\title{
ОРГАНИЗАЦИЯ ПРОИЗВОДСТВА ЛЕКАРСТВЕННЫХ СУБСТАНЦИЙ НА ОСНОВЕ СОЕДИНЕНИЙ ВИСМУТА
}

\author{
Л.И. Щербакова', Ю.М. Юхин², В.П. Щербаков', А.А. Мосман³, \\ М.А. Мездрина ${ }^{3}$, Е.С. Коледова ${ }^{2}$
}

${ }^{1}$ Общество с ограниченной ответственностью «Брайт Вэй Индастриз», 124460, Россия, г. Москва, г. Зеленоград, проспект Генерала Алексеева, д. 42, строение 1. ${ }^{2}$ Институт химии твердого тела и механохимии Сибирского отделения Российской академии наук, 630090, Россия, г. Новосибирск, ул. Кутателадзе, д. 18.

30бщество с ограниченной ответственностью «Велфарм», 640008, Россия, г. Курган, проспект Конституции, д. 11.

DOI: 10.19163/MedChemRussia2021-2021-195

E-mail:yukhin@solid.nsc.ru

Мировое потребление висмута составляет 16 тысяч тонн/год. При этом потребление висмута в виде соединений оценивается в 57,2 \%, из них в медицине - порядка 30 \%. На опытном производстве ИХТТМ СО РАН, имеющем Лицензию Минпромторга РФ на осуществление производства лекарственных средств, внедрена технология получения лекарственной субстанции висмута трикалия дицитрата, включенной Распоряжением Правительства РФ в «Перечень жизненно необходимых и важнейших лекарственных препаратов на 2020 год». Разработанная технология является принципиально новой в плане использования отечественного исходного сырья, позволяет получать высокочистый по содержанию примесных металлов и нитрат-ионов целевой продукт. На основе данной субстанции сотрудники Государственного института лекарственных средств и надлежащих практик (г. Москва) разработали противоязвенный препарат и провели доклинические исследования [1], а на ООО «Велфарм» (г. Курган) организовано производство отечественного препарата «Витридинол» типа «Де-Нол» (Нидерланды).

На ООО «Велфарм» построен цех для производства фармацевтических субстанций с целью импортзамещения лекарственных препаратов. Наряду с внедрением технологии висмут-калий-аммоний цитрата [2], в стадии разработки находится технология висмута субсалицилата для производства антидиарейного препарата типа «Десмол» (США). Планируется также размещение производства и других субстанций: висмута субнитрата, субкарбоната, цитрата и висмута галловокислого основного.

\section{Литература}

[1] Ю.М. Юхин, Е.С. Найденко, Е.М. Карпова, Л.Е. Фрумин, К.Р. Савельева, Г.Н. Хлябич, В.Н. Шестаков Противоязвенный препарат на основе субстанции висмута(III) калия дицитрата. Бутлеровские сообщения. 2014. Т. 38, № 4. С. 87-93.

[2] Патент № 2675869 РФ. Способ получения висмут-калий-аммоний цитрата. Ю.М. Юхин, В.П. Щербаков, А.А. Мосман, Е.С. Найденко, А.В. Кудряшова; заявитель и патентообладатель Общество с ограниченной ответственностью «Брайт Вэй». № 2018104239, заявл. 05.02.18, опубл. 25.12.18, Бюл. № 36. 